\title{
WHAT DO WE REALLY NEED TO MAKE A FILM?: AN INTERVIEW WITH PROFESSOR JEREMI SZANIAWSKI
}

\author{
Besna AĞIN*
}

Ağın, B. (2021). What do we really need to make a film?: An interview with Professor Jeremi Szaniawski. Etkileşim, 7, 242-247. doi: 10.32739/etkilesim.2021.7.127

This study complies with research and publication ethics. Bu çalışma araştırma ve yayın etiğine uygun olarak gerçekleştirilmiştir.

At the end of March 2020, COVID-19 forced many film productions to pause. The pandemic continues to have a huge impact on the film sector. Although many countries and film institutions provide measures in order to help productions continue in safety, the question remains as to what will become of cinema in years to come.

We talked at length with Professor Jeremi Szaniawski on the subject COVID-19 and filmmaking. Professor Szaniawski is an Assistant Professor in Comparative Literature and Film Studies at the University of Massachusetts, Amherst. He has edited, among others, the volumes The Global Auteur: The Politic of Authorship in 21st Century Cinema (with Seung-hoon Jeong, Bloomsbury, 2016) and the forthcoming Fredric Jameson and Film Theory: Marxism, Allegory, and Geopolitics in World Cinema (with Keith Wagner and Michael Cramer, Rutgers, Rutgers University Press, 2021).

-So here we are, on one hand, with reports of the death of cinema. On the other hand, many believe that the pandemic led to new opportunities in filmmaking. Well, there is no real way for theaters to make up those lost sales and eventually, they may die out, but does that mean the actual death of cinema? Isn't cinema more than just a communal experience of going with loved ones to a dark room with a big screen and smell of popcorn?

The "death of cinema", as was proclaimed by some archivists at the turn of the $21^{\text {st }}$ century, happened, in a way, around 2010-2012, when commercial cinema transitioned from analog film $(35 \mathrm{~mm})$ to digital. But that transition had absolutely no economic bearing on cinema. It only accelerated the demise of small movie theaters who could not afford the expensive digital projectors.

\footnotetext{
* Research Assistant, Üsküdar University, Faculty of Communication,
} besna.agin@uskudar.edu.tr, ORCID: 0000-0002-1591-0352

242 | ETkísşim | Üsküdar Üniversitesi |iletişim Fakültesi |Akademik Dergisi 
Now we are confronted with the economic death of movie theaters-many, if not most, will not recover from the pandemic and lockdowns. Big companies/ franchises/chains will recover: they always have other options (e.g. fusing more traditional moviegoing with $4 \mathrm{D}, \mathrm{VR}$, etc.). The experience of going to a darkened theater, with popcorn, will resume as soon (and if!) governments find a way to address the pandemic in ways that do not prohibit social gatherings. Humans, as social creatures, like to gather for events. This is unlikely to change, but it may be a while before it is actually legal/authorized to do so.

All the while, this crisis *is* and is *not* marking the death of cinema. Clearly, cinema as we knew it in the second half of the $20^{\text {th }}$ century (and particularly since the late 1970s) has undergone significant transformations which are not only technological: they are also philosophical. As such, it's fair to say that there's been a (probably irreversible) shift from a form of cinematic miseen-scène and narrative economy (for films around 90-120 minutes to watch in one sitting at the theater) to the show (with much longer narrative economies, which people can watch in one 'binge' sitting, or over the course of several days or weeks). Ever since the 1980 s, the majority of revenues of movies were no longer in theater ticket sales: they were displaced to TV rights, home entertainment rights, etc. Theater releases were more like a 'marquee' or prestige thing than a real economic argument. Since 2012 at least, you would see huge billboards in Los Angeles advertising new online platform shows. Today, these online platforms are the primary source of such audiovisual material for people to consume. In this sense, we have witnessed the "death of cinema". But it is also not a 'death', rather a transformation. All major media and artforms undergo such changes and transformations through their history. It is exciting to see what will happen of 'cinema' now, all the while accepting that what defined cinema in the $20^{\text {th }}$ century is now gone.

-In a world where everything has changed, filmmakers have experienced their first COVID sets. The pandemic has changed how film sets operate and filmmakers are adjusting to the 'new normal'. Viewing habits have already changed in ways that will have long-term effects. The experience of moviegoing has already become far less common. In addition, we know that even before the pandemic streaming video on-demand (SVOD) was having a huge impact on the industry. In this context, is it possible to say that COVID-19 has permanently altered the production, distribution and viewing of films? Is the pandemic only accelerating the ongoing transformation in film production and distribution?

The short answer is yes: most definitely, the pandemic has served as a shock and accelerator of a transformation that was already ongoing. The production, distribution and viewing of films had been undergoing a significant transformation at least since the late 00s (around the time when Netflix killed its in-the-mail film delivery service and became a streaming/VOD platform with its own original material). 
Now as regards the human factor: the pandemic has had a hugely negative impact on the livelihood of most people working in the arts and entertainment industries-particularly lower rank technicians. Still, film and shows crews were (relatively) spared compared to performing arts people (stage, opera, etc.). But this 'impact' of the pandemic (or, rather, of the way governments have responded to the pandemic) has been felt by a lot of professions and industries (think of hospitality, restaurants, which are hit way, way worse). As a matter of fact, now that new measures are in place to minimize the risk of spreading of the virus (regular PCR testing, wearing facemasks, disinfecting hands and surfaces, observing social distancing), film shoots can probably be conducted more or less the way they were. There is a huge and constant demand by networks and platforms to generate new audiovisual material, especially as people are stuck at home in many parts of the global north, with often no better idea of what to do but to watch shows on Netflix, Amazon Prime, or other such platforms (a shoutout here to the Turkish site Mubi, which I like a lot).

I think that the film industry has attracted more attention to its plight during the pandemic, because it is an industry that has a natural access to media platforms and to publicity. Think, for instance, of all the 'stories' around famous actors getting COVID-19 (Tom Hanks a case in point) and telling about their bout with the virus. Millions of people got COVID-19 and did not receive the same treatment. Tom Hanks reported some body aches, fatigue. It was front page in many media outlets. Hundreds of thousands of people died of COVID-19 but did not receive an individual treatment. The same applies with the industry as a whole: film and show productions were affected by the pandemic, and, I would argue, to a lesser extent than other industries that were shut down entirely. Proportionally the 'buzz' around the plight of film and media has been excessive, and in a way, rather obscene. This is not very surprising, for many reasons, ranging from the ancillary rapports between the media and entertainment industry, to a sense of entitlement and certain over-tendency to performativity and narcissism among many people working in that industry.

-Studios spend hundreds of millions of dollars, or even a billion for films in return for budgets in the $\$ 150$ million range. This is what we call the blockbuster model. But with the pandemic, things have turned upside down. Not even "Tenet", "Wonder Woman 1984" or "Mulan" could save the movie theaters. We know that the release of the next James Bond film has been delayed again. The film has now been further delayed until 2 April 2021 "in order to be seen by a worldwide theatrical audience", according to a statement on the film's website. But what does that mean? Does the idea of waiting out the pandemic to release films "in order to be seen by a worldwide theatrical audience" actually make sense? Is it possible to say that the studios can't face the truth that the economics of film will change? 
You are discussing revenues in ticket sales, but evidently the majority of the investment is recouped in other ways, including home entertainment and TV/VOD rights. The pandemic may hurt these films' commercial fortunes but won't kill them. Wonder Woman 1984 was already moved to straight-to-VOD release. With the latest James Bond, it's such a prestigious (and conservative!) franchise, that they are still hoping to have that marquee thing going on, the theatrical release, especially to capitalize on the spectacular dimension (big screen, sound effects, etc. - the same applied of course to Nolan's Tenet). But they could just as well go straight to VOD. There is this technological gap, here... We are still waiting for VR helmets and home entertainment to catch up with the new world. These few and far between blockbusters are holed in between two major paradigms of entertainment experience. It's not like any of these token blockbusters mean anything in the grander scheme of things. The industry reached some sort of apex in the spring of 2019, with Avengers: Endgame beating the previous record of Avatar (of course if you keep inflation into account, the film did *not* beat Avatar, but that's a contentious point). The industry is always seeking new frontiers, it's one of its driving forces. The pandemic is a good opportunity for these new frontiers to be probed indeed.

-Due to the pandemic, filmmakers have to be very creative in where and how they shoot their films. A different kind of creativity has emerged. Even before the pandemic, smaller films were increasingly being financed and shown on streaming services. Do you think the pandemic will alter the kind of films that people make? Will there be scripts that are mainly focused on solo characters, few locations, limited romance and so forth?

I think the pandemic (and the hardships it has caused) ought to generate philosophical and psychological questioning. The world witnessed the amazing emergence of Italian neorealism after World War II. One would hope that the world crisis we are witnessing will generate new ways of telling stories and of thinking the world, our place in it, and our relationship to one another as human beings and sentient subjects. The little 'DIY' tricks or 'practical solutions' to the epidemiological dimension of the crisis are, in my opinion, but a material consideration, with a marginal consequence on the art of audiovisual storytelling, but, surely, there will be a quantitative impact on narratives that will address lockdowns, isolation, etc. I would however expect creativity to not come out of studios or corporations, but of the wonderful 'hive' of millions (or billions!) of practitioners of audiovisual production, with the help of a simple smartphone. The problem of this tremendous and wonderful creativity is that it doesn't get seen much, or that it gets coopted (or stolen) by big companies, always on the prowl for good or striking ideas -or accumulating data.

So, all that will have some impact on film form, but it's vastly secondary to the philosophical impact and implications of the crisis the world has been witnessing. Where the real question lies: if we consider that this crisis is also 
about a crisis of democracy, of liberalism, and of capitalism at large - what kind of texts will emerge 'on the other side'?

-What do you think filmmakers will do when it comes to incorporating the pandemic into their stories? On one hand, it is hard for them to pretend the pandemic doesn't exist. But on the other hand, acknowledging it poses its own challenges.

Absolutely. Scenes of physical contact, for instance, will be scrutinized or experienced differently by audiences (even at the subconscious level). Surely new genres will emerge, and existing genres will address this (comedy, of course, but also thrillers and horror films!). There will be -at least for a little while- that thing called COVID-19 going on in everyone's mind. Entertainment is meant to at once distract and discipline (or even control) masses. The question is which direction will somehow prevail, here. Surely there will be a need for escapism -films set in a different time zone, where people can 'switch off' the COVID-19 part of their brains; and films set in the COVID-19 ега, playing with or on the very crisis itself.

What is fascinating, with films that have addressed a pandemic (think of Petersen's Outbreak or Soderbergh's Contagion) -besides the eerie parallels to be drawn with the media handling of the crisis itself- is the sense of happy ending and amnesia that seems to happen at the (happy) end. This poses interesting and challenging questions in the way audiovisual temporality and memory will be affected in the near future. Deleuze spoke of 'time-image' after World War II. What new 'images' this latest instantiation of global capitalism we are about to discover remains a fascinating and exciting question.

-In a world 'after coronavirus', is it possible to say that cinema will come back stronger in terms of stories, narrative and aesthetic?

We don't know if there will be a world 'after coronavirus'. Nobody can tell (or if they can, they clearly have some ulterior motives!) what will happen with this virus. We may have to learn and live with it, whatever that means. If so, hopefully therapeutics and vaccines can be developed and combined in such ways as to turn this crisis and pandemic into another 'habitual' seasonal virus. Maybe -like the Spanish flu- the virus will peter out and go away later this year. Who can tell! What is certain is that the economic devastation on the middle and lower classes, and small businesses, will be unprecedented. Corporate capitalism will take over, probably overtaking many nation states in terms of economic power. If movie theaters and malls are still part of the business models envisioned by this new stage in capitalism, then surely commercial cinema will come back. While new technologies will not cease flowing, I leave the narrative and aesthetics stakes in the hands of artists and supremely attuned intellectuals. They don't need big tech to produce superb films - they

246| ETKiLeşim | Yıl 4 |Sayı 7 |Nisan 2021 
need inner and outer worlds filled with human communities. Think of someone like Hong Sang-soo (however reviled in his own country, and however problematic in many ways, he is, by a landslide, the greatest South Korean filmmaker). Can he continue to make superb, super low budget films in a world where human communities are vastly reduced to conform to sanitary rules? That is a great question and a great challenge. Can some artists -especially with particular forms of antisocial obsessions or autism, whose creativity, conversely, is hampered by what they experience as overstimulation when in contact with a lot of people- thrive in this period? I would not dare to venture an answer.

-Because of the pandemic, the future has been pulled forward. Maybe, it is time to embrace a new way of thinking in terms of filmmaking. And all we have discussed so far brings us to one big question. In order to make a film, what do we really need?

Indeed, the pandemic has accelerated the dialectics of history and precipitated this new stage in world capitalism. Anyone who thinks we will go back to the neoliberal status quo after this crisis has been overcome doesn't understand how History works. Many who do understand how History functions fear this near future may be totalitarian and antihumanist (the term en vogue is 'transhumanist', whatever that means depending on who wields the concept). Cinema was always a strange and conflicted medium where cruelty and even forms of vicious psychopathologies, greed and obsessions with control somehow managed, sometimes, to produce great, inspiring works of art with a powerful human factor at the center. A great popular art. Perhaps (perhaps!), by the same logic, something great will emerge from the current situation, which is otherwise so sad and tragic. As to your question: while in order 'to make a film', all you need is some technology and some technicians (be they human or algorithms), in order to make cinema, you need -sure- a good story!, but what you really need, for the philosophical undergirding of the good story to take hold and give depth to the rest, is a community of human beings, a real, lived-in socioeconomic system, a philosophy and awareness of history, which may amount to an Idea to counter the pedestrian considerations that make up any such enterprise. You know the old adage 'what's the story about? ... and what's the story really about?' This doubling of the narrative apparatus is only just the beginning.

-Thank you indeed, Professor Szaniawski.

Conflict of interest: There are no conflicts of interest to declare.

Financial support: No funding was received for this study.

Çıkar çatışması: Çıkar çatışması bulunmamaktadır.

Finansal destek: Finansal destek bulunmamaktadır. 